\title{
Evidence that Gag facilitates HIV-1 envelope association both in GPI-enriched plasma membrane and detergent resistant membranes and facilitates envelope incorporation onto virions in primary $\mathrm{CD}^{+} \mathrm{T}$ cells
}

\author{
Ajit Patil $^{\dagger}$, Archana Gautam ${ }^{\dagger}$, Jayanta Bhattacharya ${ }^{*}$
}

\begin{abstract}
HIV-1 particle assembly mediated by viral Gag protein occurs predominantly at plasma membrane. While colocalization of HIV-1 envelope with lipid rich microenvironment have been shown in T cells, the significance of viral proteins modulating envelope association in such microdomains in plasma membrane enriched in glycosylphosphatidylinositol-anchored proteins in primary $\mathrm{CD}^{+} \mathrm{T}$ cells that are natural targets of HIV-1 is poorly understood. Here we show that in primary $\mathrm{CD}^{+}{ }^{+} \mathrm{T}$ cells that are natural targets of HIV-1 in vivo, Gag modulates HIV-1 envelope association with GM1 ganglioside and CD59 rich cellular compartments as well as with detergent resistant membranes. Our data strengthen evidence that Gag-Env interaction is important in envelope association with lipid rafts containing GPI-anchored proteins for efficient assembly onto mature virions resulting in productive infection of primary $\mathrm{CD}^{+} \mathrm{T}$ cells.
\end{abstract}

\section{Findings}

Human Immunodeficiency Virus Type 1 (HIV-1) has been shown to assemble via specialized plasma membrane domains popularly known as lipid rafts [1-6], which are rich in cholesterol and sphingomyelin within an ordered structure and plays important role in cell signaling [7]. Rafts are believed to play an important role towards facilitating HIV-1 assembly particularly exploiting acylated residues in viral Gag $[1,3,5]$ and envelope (Env) $[8,9]$. However, the precise mechanism by which lipid rafts functions in targeting viral Env and Gag to the plasma membrane in infected $\mathrm{T}$ cells and facilitate assembly is not clearly understood. Previously, Jolly and Sattentau [10] have shown that raft integrity is critical for Env and Gag co-clustering and assembly in $\mathrm{T}$-cell conjugates. Thus, mere presence of non raft proteins such as CD45 phosphatase in HIV-1 envelope

\footnotetext{
* Correspondence: jbhattacharya@nariindia.org

† Contributed equally

Division of Molecular Virology, National AIDS Research Institute, G-73 MIDC, Bhosari, Pune-411026, India
}

(C) 2010 Patil et al; licensee BioMed Central Ltd. This is an Open Access article distributed under the terms of the Creative Commons Attribution License (http://creativecommons.org/licenses/by/2.0), which permits unrestricted use, distribution, and reproduction in any medium, provided the original work is properly cited.

glycoprotein while abundant incorporation of raft lipid components such as ganglioside GM1, glycosylphosphatidylinositol (GPI)-anchored proteins Thy-1 and CD59 strongly suggest that HIV-1 specifically buds from rafts [5,11]. A stable interaction between intracellular Pr55Gag and the gp41 cytoplasmic domain of envelope [12] was shown to be important for envelope association with detergent resistant membranes, incorporation onto virions and infectivity $[13,14]$. The precise sequence by which envelope utilizes cellular machinery in migrating towards the site of viral assembly is not clearly understood. Glycoproteins of several enveloped viruses, have been found to contain lipid moieties $[15,16]$ and has generated notion on the importance of lipid rafts as a docking site for the assembly of enveloped viruses [17-22]. Association of HIV-1 envelope with polarized lipid raft markers GM1 and CD59 was shown to influence transmission between T cells [10]. Gag has been shown to play an important role in envelope assembly onto virions, notably by interaction of its p17 matrix domain with gp41 cytoplasmic domain of envelope 


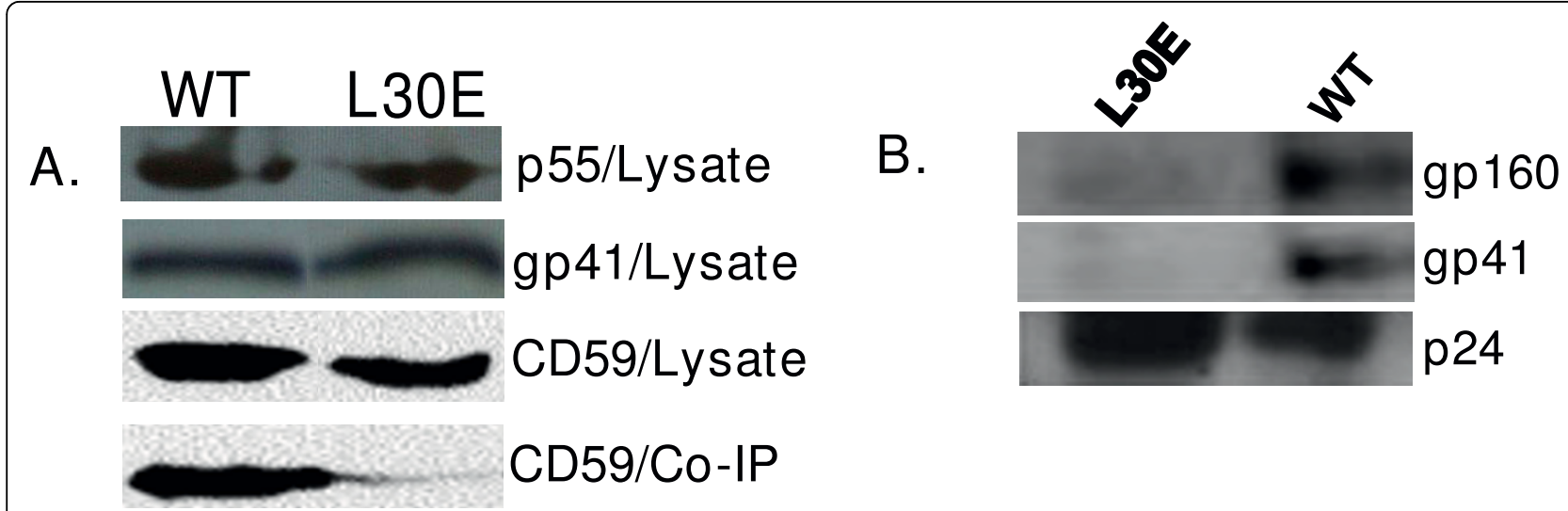

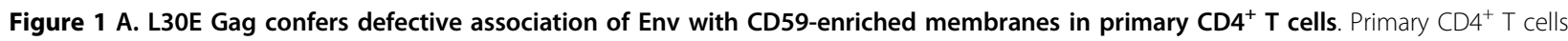
infected with VSV-G pseudotyped pNL4.3 and pNL4.3 (L30E) were lyzed and intracellular p55, gp41 and CD59 contents were measured in total cell lysates (as shown here in upper panels). Cell lysates expressing comparable p55 and gp41 were immunoprecipitated with gp41 antibodies 2F5 and 4E10 as described in the Materials and Methods resolved in 12.5\% SDS-PAGE and electrophoretically transferred onto PVDF membrane. The level of CD59 co-immunoprecipitated with envelope was detected by Western blotting using monoclonal anti-CD59 antibody. B. Defective incorporation of HIV-1 envelope proteins onto virus particles due to L30E Gag substitution. Equal amounts of cell free virus particles were resolved in SDS-PAGE and Western blotting done by monoclonal antibodies to gp41 and p24 as described in the text. Note that with L30E gag mutation, envelope incorporation onto virions is severely abrogated.

[14,23-25]. While HIV Gag intrinsically associates with detergent resistant membranes (DRMs) [5,26], influenza virus M1 protein transport to DRMs depends on coexpression of HA and NA glycoproteins [27]. Likewise, the association of Sendai virus M protein in DRM is dependent on expression of $\mathrm{F}$ or $\mathrm{HN}$ protein [28], while the Rous sarcoma virus $M$ protein requires expression with the F protein for DRM association [29]. In contrast, the Measles virus $M$ protein has been shown to associate DRMs intrinsically independent of other viral proteins [30]. Motifs in gp41 cytoplasmic domain regulating association of HIV-1 envelope protein with DRM [8] and this phenomenon is Gag dependent in a $\mathrm{T}$ cell line [13] was previously reported. However, it was not known whether this phenomenon is cell type-dependent and if it differs between cell lines and those that are natural targets in vivo. Moreover, whether DRM association of envelope corroborates with their ability to traffic to classical lipid rafts was also not known. In the present study we investigated the role of Gag in intracellular transport of HIV-1 envelope into well defined GPI-anchored proteins such as CD59 and GM1 (monosialotetrahexosylganglioside) and its relevance of envelope assembly onto budding virions in primary $\mathrm{CD}_{4}^{+} \mathrm{T}$ cells. Precisely, we examined whether a point mutation (L30E) in matrix domain of Gag known for disrupting Env incorporation [23,31] affects envelope trafficking to CD59+ compartment in primary $\mathrm{CD} 4^{+} \mathrm{T}$ cells and if this phenomenon has any association with cellfree infectivity in primary $\mathrm{CD} 4^{+} \mathrm{T}$ cells.

We first examined whether a point mutation (L30E) in matrix domain of Gag previously reported to abrogate envelope incorporation, infectivity [23] and DRM association [13] in cell lines affect infectivity and modulate envelope association with CD59-enriched compartment in primary $\mathrm{CD}_{4}^{+} \mathrm{T}$ cells which are predominantly the natural targets in vivo during entire course of HIV-1 infection. CD59 marker was selected as it is linked with phosphatidylinositol and segregates into rafts. Primary $\mathrm{CD} 4^{+} \mathrm{T}$ cells were purified by negative selection from whole blood using RosetteSep ${ }^{\circ}$ Kit (Stem Cell Technologies Inc.) following manufacturer's protocol. Briefly, $\mathrm{CD}^{+}{ }^{+} \mathrm{T}$ Cell Enrichment Cocktail was added at a final concentration of $50 \mu \mathrm{l} / \mathrm{ml}$ of whole blood and incubated at room temperature for $20 \mathrm{~min}$. The mixture was diluted with RPMI/2\% Fetal Bovine Serum (GIBCO, Inc), layered onto Ficoll Hypaque (Sigma, Inc) and centrifuged for $20 \mathrm{~min}$ at $1200 \times \mathrm{g}$ at room temperature. The enriched $\mathrm{CD} 4^{+} \mathrm{T}$ cells in the interface of density medium and plasma yielded approximately $98 \%$ purity; subsequently stimulated with phytohemagglutinin $(0.5$ $\mathrm{ug} / \mathrm{ml})$ and interleukin-2 (10-20 U/ml) before infection with virus stocks. Primary $\mathrm{CD} 4^{+} \mathrm{T}$ cells were infected with equal infectivity titers of VSV-G pseudotyped pNL4.3 WT and pNL4.3 L30E viruses and the cell lysates made from $\mathrm{CD} 4^{+} \mathrm{T}$ cells infected with wild type and L30E expressing equal amounts of p24 and gp41 were incubated with anti-gp41 monoclonal antibodies to immuno-precipitate Env. Briefly, $\mathrm{CD}^{+}{ }^{+} \mathrm{T}$ cells were lyzed with $1 \%$ Triton X-100 in PBS (pH 7.4), and incubated with 1:1 mixture of gp41 monoclonal antibodies 2F5 and 4E10 (1:1000 dilution) for 4 hours at $4^{\circ} \mathrm{C}$ followed by additional 1 hour incubation with Protein A/G 

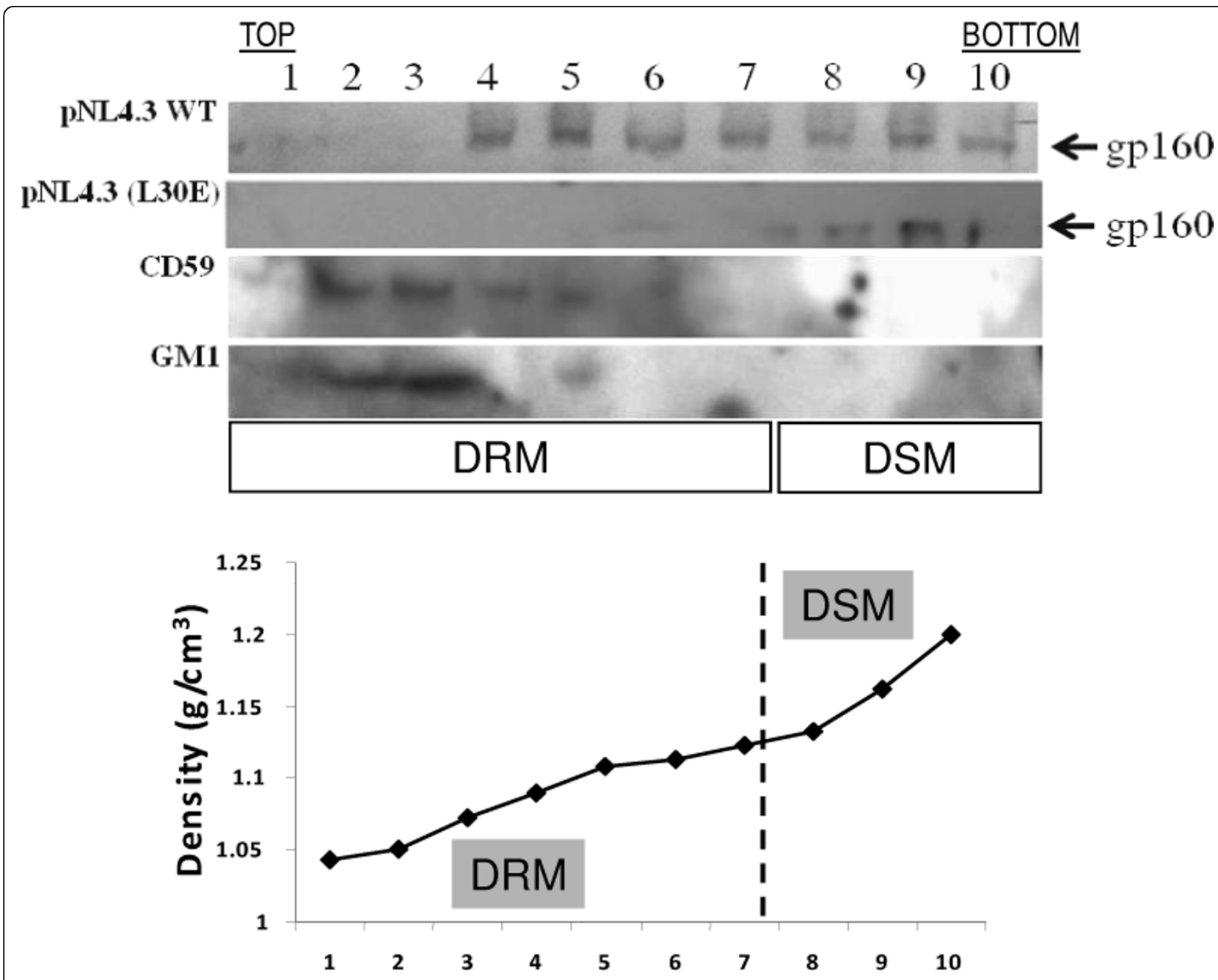

Fraction Numbers

Figure 2 Envelope association with DRM in primary CD4 ${ }^{+} \mathbf{T}$ cells. A. CD4 ${ }^{+} T$ cells infected with VSV-G pseudotyped pNL4.3 and pNL4.3 (L30E) were treated with cold Triton-X 100 and fractionated in sucrose density gradients as described in the text. Gradient fractions were subsequently probed for envelope with gp41 antibodies 2F5 and 4E10, anti-human CD59 for CD59 and CTxB-HRP for GM1 by SDS-PAGE followed by Western blotting. B. Density $\left(\mathrm{g} / \mathrm{cm}^{3}\right)$ of fractions showing DRM and DSM (detergent soluble membrane) fractions [39].

beads (Pierce Inc). Lysates were further washed with cold PBS and were resolved in 12\% SDS-PAGE under denaturing conditions. Equal amounts of immunoprecipitated materials were subjected to $12 \%$ SDS-PAGE under denaturing conditions [32], transferred onto PVDF membranes and subsequently Western blot assay done with anti-human CD59 antibody (at 1: 1000 dilution) to assess the ability of Env association with CD59enriched compartment. As shown in Figure 1A, due to L30E mutation in Gag, Env failed to recruit CD59 in contrast to pNL4.3 wild type. Our data indicate that the mutation in Gag MA region (L30E) restricts the interaction between Gag and Env resulting in down modulation of envelope trafficking to GPI-anchored membranes in primary $\mathrm{CD} 4^{+} \mathrm{T}$ cells such as CD59. Moreover, in order to assess the effect of L30E mutation in p17 gag on HIV-1 envelope incorporation on virions in primary $\mathrm{CD} 4^{+} \mathrm{T}$ cells, cell-free virus pellets were obtained by centrifugation as described previously [13]. Equal amounts of virus particles (p24) were resolved in SDSPAGE under denaturing conditions followed by Western blotting using monoclonal antibodies to p24 (183-H125C) and gp41 (1:1 of 2F5 and 4E10). As shown in Figure 1B, L30E substitution in p17 Gag was found to drastically affect envelope incorporation onto virus particles in $\mathrm{CD} 4^{+} \mathrm{T}$ cells as expected.

We next assessed if there is any correlation between disruptions of envelope association with CD59+ compartment in primary $\mathrm{CD} 4^{+} \mathrm{T}$ cells and its association with DRM of the same cell type. The DRM assay was 
carried out essentially as described previously [8]. Briefly, primary $\mathrm{CD} 4^{+} \mathrm{T}$ cells infected with VSV-G pseudotyped pNL4.3 WT and pNL4.3 (L30E) were lyzed with cold $0.5 \%$ Triton-X-100 and fractionated through sucrose density gradient centrifugation in an ultracentrifuge (Beckman Coulter Inc) at 1,00,000 $\times$ g for $8-12$ hours at $4^{\circ} \mathrm{C}$. Ten equal fractions were collected and were examined for presence of gp160, CD59 and GM-1 ganglioside by Western blot using human anti-gp41 monoclonal antibody (2F5) [31] and 4E10 [33], mouse anti-human CD59 (BD Biosciences Inc) and cholera toxin conjugated to horse radish peroxidase (HRP) (Sigma, Inc.) respectively. As shown in Figure 2, L30E mutation in Gag restricted envelope association with DRM fractions of $\mathrm{CD} 4^{+} \mathrm{T}$ cells in contrast to the wild type. Our results were further substantiated by the presence of both CD59 and GM1 in DRM fractions under same experimental conditions.

In summary, we show the modulatory role of Gag on envelope association with lipid enriched micro domain that play an important role in transmission by modulating envelope assembly onto virus particles in primary $\mathrm{CD}^{+} \mathrm{T}$ cells. Despite its close proximity, DRMs isolated from cells may not necessarily represent the preexisting rafts in living cells. [34,35]. Hence, GPI anchored proteins because of their raftofilcity often are regarded as best choice for studying raft association and targeting [36]. In our present study, in addition to investigate role of gag in envelope association with DRM, we attempted to look into GPI-anchored proteins for their high affinity towards lipid raft association [35,37]. The lipidbinding $\mathrm{B}$ subunit of cholera toxin $(\mathrm{CTxB})$, recognizing GM1 at cell surface in plasma membrane, was used to study the envelope transport into lipid rafts. Like other GPI-anchored proteins, these markers were also known to be associated with DRM [38]. Our data showed that abrogation of Gag-Env interaction down modulated envelope transport into CD59 positive compartment in primary $\mathrm{CD} 4^{+} \mathrm{T}$ cells and also failed to associate with DRM fractions. While viral precursors Gag and Gag-Pol are synthesized by polysomes in cellular cytoplasm, the oligomeric envelope protein is synthesized in endoplasmic reticulum and post-translationally modulated in the Golgi apparatus, traverses into the secretory pathway towards assembling onto budding virions. We envisage that Gag by acting as cargo transport intermediate carry envelope protein through trans-golgi route sorting into domains of lipid rich plasma membrane enable them assemble onto budding virions in primary $\mathrm{CD} 4^{+} \mathrm{T}$ cells.

\section{List of abbreviations}

DRM: detergent resistant membrane; GM1: monosialotetrahexosylganglioside; GPI: glycosylphosphatidylinositol; GHOST: human osteosarcoma cells expressing CD4 and green fluorescent protein; CTxB: cholera toxin-b subunit.

\section{Acknowledgements}

We thank Dr. Paul Clapham, UMASS Medical School, and Worcester, USA for providing GHOST-CXCR4 cell line and Dr. Bhaskar Saha, National Center for Cell Science; Pune for help with ultracentrifugation required for DRM assays. We thank NIH AIDS Reagent and Reference Program for 183-H12-5C

Hybridoma, 2F5 and 4E10 monoclonal antibodies. This study was supported by a fellowship grant from American Foundation of AIDS Research (amfAR) to JB (106658-36-RFNT).

\section{Authors' contributions}

JB has designed the study; AP and AG have performed the experiments; AP and $A G$ helped $J B$ in writing the manuscript. All the authors have read and approved the final manuscript.

\section{Competing interests}

The authors declare that they have no competing interests.

Received: 4 November 2009

Accepted: 8 January 2010 Published: 8 January 2010

\section{References}

1. Campbell SM, Crowe SM, Mak J: Lipid rafts and HIV-1: from viral entry to assembly of progeny virions. J Clin Virol 2001, 22:217-227.

2. Ding L, Derdowski A, Wang JJ, Spearman P: Independent segregation of human immunodeficiency virus type $1 \mathrm{Gag}$ protein complexes and lipid rafts. J Virol 2003, 77:1916-1926.

3. Holm K, Weclewicz K, Hewson R, Suomalainen M: Human immunodeficiency virus type 1 assembly and lipid rafts: Pr55(gag) associates with membrane domains that are largely resistant to Brij98 but sensitive to Triton X-100. J Virol 2003, 77:4805-4817.

4. Lindwasser OW, Resh MD: Multimerization of human immunodeficiency virus type $1 \mathrm{Gag}$ promotes its localization to barges, raft-like membrane microdomains. J Virol 2001, 75:7913-7924.

5. Nguyen $\mathrm{DH}$, Hildreth JE: Evidence for budding of human immunodeficiency virus type 1 selectively from glycolipid-enriched membrane lipid rafts. J Virol 2000, 74:3264-3272.

6. Ono A, Freed EO: Plasma membrane rafts play a critical role in HIV-1 assembly and release. Proc Natl Acad Sci USA 2001, 98:13925-13930.

7. Harder T, Engelhardt KR: Membrane domains in lymphocytes - from lipid rafts to protein scaffolds. Traffic 2004, 5:265-275.

8. Bhattacharya J, Peters PJ, Clapham PR: Human immunodeficiency virus type 1 envelope glycoproteins that lack cytoplasmic domain cysteines: impact on association with membrane lipid rafts and incorporation onto budding virus particles. J Virol 2004, 78:5500-5506.

9. Rousso I, Mixon MB, Chen BK, Kim PS: Palmitoylation of the HIV-1 envelope glycoprotein is critical for viral infectivity. Proc Natl Acad Sci USA 2000, 97:13523-13525.

10. Jolly C, Sattentau QJ: Human immunodeficiency virus type 1 virological synapse formation in T cells requires lipid raft integrity. J Virol 2005, 79:12088-12094.

11. Chazal N, Gerlier D: Virus Entry, Assembly, Budding, and Membrane Rafts. Microbiology and Molecular Biology Reviews 2003, 67:226-237.

12. Wyma DJ, Kotov A, Aiken C: Evidence for a stable interaction of gp41 with $\operatorname{Pr} 55(\mathrm{Gag})$ in immature human immunodeficiency virus type 1 particles. J Virol 2000, 74:9381-9387.

13. Bhattacharya J, Repik A, Clapham PR: Gag Regulates Association of Human Immunodeficiency Virus Type 1 Envelope with Detergent-Resistant Membranes. J Virol 2006, 80:5292-5300.

14. Freed EO, Martin MA: Domains of the human immunodeficiency virus type 1 matrix and gp41 cytoplasmic tail required for envelope incorporation into virions. J Virol 1996, 70:341-351.

15. Aloia RC, Tian H, Jensen FC: Lipid composition and fluidity of the human immunodeficiency virus envelope and host cell plasma membranes. Proc Natl Acad Sci USA 1993, 90:5181-5185. 
16. Aloia RC, Jensen FC, Curtain CC, Mobley PW, Gordon LM: Lipid composition and fluidity of the human immunodeficiency virus. Proc Natl Acad Sci USA 1988, 85:900-904

17. Li M, Yang C, Tong S, Weidmann A, Compans RW: Palmitoylation of the murine leukemia virus envelope protein is critical for lipid raft association and surface expression. J Virol 2002, 76:11845-11852.

18. Manie SN, Debreyne S, Vincent S, Gerlier D: Measles virus structura components are enriched into lipid raft microdomains: a potential cellular location for virus assembly. J Virol 2000, 74:305-311.

19. Ochsenbauer-Jambor C, Miller DC, Roberts CR, Rhee SS, Hunter E: Palmitoylation of the Rous sarcoma virus transmembrane glycoprotein is required for protein stability and virus infectivity. J Virol 2001, 75:1154411554.

20. Zurcher T, Luo G, Palese P: Mutations at palmitoylation sites of the influenza virus hemagglutinin affect virus formation. J Virol 1994, 68:5748-5754.

21. Fleming EH, Kolokoltsov AA, Davey RA, Nichols JE, Roberts NJ Jr: Respiratory syncytial virus $\mathrm{F}$ envelope protein associates with lipid rafts without a requirement for other virus proteins. J Virol 2006, 80:1216012170.

22. Lopez LA, Riffle AJ, Pike SL, Gardner D, Hogue BG: Importance of conserved cysteine residues in the coronavirus envelope protein. J Virol 2008, 82:3000-3010.

23. Freed EO, Martin MA: Virion incorporation of envelope glycoproteins with long but not short cytoplasmic tails is blocked by specific, single amino acid substitutions in the human immunodeficiency virus type 1 matrix. $J$ Virol 1995, 69:1984-1989.

24. Freed EO, Orenstein JM, Buckler-White AJ, Martin MA: Single amino acid changes in the human immunodeficiency virus type 1 matrix protein block virus particle production. J Virol 1994, 68:5311-5320.

25. Hourioux $C$, Brand $D$, Sizaret $P Y$, Lemiale $F$, Lebigot $S$, Barin F, Roingeard $P$. Identification of the glycoprotein 41(TM) cytoplasmic tail domains of human immunodeficiency virus type 1 that interact with Pr55Gag particles. AIDS Res Hum Retroviruses 2000, 16:1141-1147.

26. Ono A, Freed EO: Role of lipid rafts in virus replication. Adv Virus Res 2005, 64:311-358.

27. Ali A, Avalos RT, Ponimaskin E, Nayak DP: Influenza virus assembly: effect of influenza virus glycoproteins on the membrane association of M1 protein. J Virol 2000, 74:8709-8719.

28. Ali A, Nayak DP: Assembly of Sendai virus: $M$ protein interacts with $F$ and $\mathrm{HN}$ proteins and with the cytoplasmic tail and transmembrane domain of $F$ protein. Virology 2000, 276:289-303.

29. Henderson G, Murray J, Yeo RP: Sorting of the respiratory syncytial virus matrix protein into detergent-resistant structures is dependent on cellsurface expression of the glycoproteins. Virology 2002, 300:244-254

30. Manie SN, Debreyne S, Vincent S, Gerlier D: Measles virus structural components are enriched into lipid raft microdomains: a potential cellular location for virus assembly. J Virol 2000, 74:305-311.

31. Buchacher A, Predl R, Strutzenberger K, Steinfellner W, Trkola A, Purtscher M, Gruber G, Tauer C, Steindl F, Jungbauer A, Katinger H: Generation of human monoclonal antibodies against HIV-1 proteins; electrofusion and Epstein-Barr virus transformation for peripheral blood lymphocyte immortalization. AIDS Res Hum Retroviruses 1994, 10:359-369.

32. Laemmli UK: Cleavage of structural proteins during the assembly of the head of bacteriophage T4. Nature 1970, 227:680-685.

33. Stiegler G, Kunert R, Purtscher M, Wolbank S, Voglauer R, Steindl F, Katinger $\mathrm{H}$ : A potent cross-clade neutralizing human monoclonal antibody against a novel epitope on gp41 of human immunodeficiency virus type 1. AIDS Res Hum Retroviruses 2001, 17:1757-1765.

34. Melkonian KA, Chu T, Tortorella LB, Brown DA: Characterization of proteins in detergent-resistant membrane complexes from Madin-Darby canine kidney epithelial cells. Biochemistry 1995, 34:16161-16170.

35. Brown DA: Lipid rafts, detergent-resistant membranes, and raft targeting signals. Physiology (Bethesda) 2006, 21:430-439.

36. Brown DA, London E: Functions of lipid rafts in biological membranes. Annu Rev Cell Dev Biol 1998, 14:111-136.

37. Legler DF, Doucey MA, Schneider P, Chapatte L, Bender FC, Bron C: Differential insertion of GPI-anchored GFPs into lipid rafts of live cells. Faseb J 2005, 19:73-75.
38. Orlandi PA, Fishman PH: Filipin-dependent inhibition of cholera toxin: evidence for toxin internalization and activation through caveolae-like domains. J Cell Biol 1998, 141:905-915.

39. Dolganiuc $V$, McGinnes L, Luna EJ, Morrison TG: Role of the cytoplasmic domain of the Newcastle disease virus fusion protein in association with lipid rafts. J Virol 2003, 77:12968-12979.

doi:10.1186/1743-422X-7-3

Cite this article as: Patil et al:: Evidence that Gag facilitates HIV-1 envelope association both in GPI-enriched plasma membrane and detergent resistant membranes and facilitates envelope incorporation onto virions in primary CD4 ${ }^{+}$T cells. Virology Journal 2010 7:3.
Publish with Biomed Central and every scientist can read your work free of charge

"BioMed Central will be the most significant development for disseminating the results of biomedical research in our lifetime. "

Sir Paul Nurse, Cancer Research UK

Your research papers will be:

- available free of charge to the entire biomedical community

- peer reviewed and published immediately upon acceptance

- cited in PubMed and archived on PubMed Central

- yours - you keep the copyright 